\title{
Synthesis and formulation studies of griseofulvin analogues with improved solubility and metabolic stability
}

Petersen, Asger Bjørn; Andersen, Nikolaj Sten; Konotop, Gleb; Hanafiah, Nur Hafzan Md; Raab, Marc S.; Krämer, Alwin; Clausen, Mads Hartvig

\author{
Published in: \\ European Journal of Medicinal Chemistry
}

Link to article, DOI:

10.1016/j.ejmech.2017.02.055

Publication date:

2017

Document Version

Peer reviewed version

Link back to DTU Orbit

Citation (APA):

Petersen, A. B., Andersen, N. S., Konotop, G., Hanafiah, N. H. M., Raab, M. S., Krämer, A., \& Clausen, M. H. (2017). Synthesis and formulation studies of griseofulvin analogues with improved solubility and metabolic stability. European Journal of Medicinal Chemistry, 130, 240-247. https://doi.org/10.1016/j.ejmech.2017.02.055

\section{General rights}

Copyright and moral rights for the publications made accessible in the public portal are retained by the authors and/or other copyright owners and it is a condition of accessing publications that users recognise and abide by the legal requirements associated with these rights.

- Users may download and print one copy of any publication from the public portal for the purpose of private study or research.

- You may not further distribute the material or use it for any profit-making activity or commercial gain

- You may freely distribute the URL identifying the publication in the public portal 


\section{Synthesis and Formulation Studies of Griseofulvin Analogues with}

\section{Improved Solubility and Metabolic Stability}

Asger B. Petersen, ${ }^{\dagger}$ Nikolaj S. Andersen, ${ }^{\dagger}$ Gleb Konotop, ${ }^{\ddagger}$ Nur Hafzan Md Hanafiah, ${ }^{\ddagger, ø}$ Marc S. Raab, ${ }^{\ddagger}$ Alwin Krämer, ${ }^{\S}$ and Mads H. Clausen ${ }^{\dagger, *}$

†Center for Nanomedicine and Theranostics \& Department of Chemistry, Technical University of Denmark, Kemitorvet 207, DK-2800 Kgs. Lyngby, Denmark.

${ }^{\ddagger}$ Max-Eder Research Group "Experimental Therapies for Hematologic Malignancies", German Cancer Research Center (DKFZ) and Department of Internal Medicine V, University of Heidelberg, 69120 Heidelberg, Germany.

aDepartment of Clinical Pharmacy, School of Pharmaceutical Sciences, Universiti Sains Malaysia, 11800 USM, Malaysia.

${ }^{\S}$ Clinical Cooperation Unit Molecular Hematology/Oncology, German Cancer Research Center and Department of Internal Medicine V, University of Heidelberg, 69120 Heidelberg, Germany.

*Corresponding author, Center for Nanomedicine and Theranostics \& Department of Chemistry, Technical University of Denmark, Kemitorvet 207, DK-2800 Kgs. Lyngby, Denmark. Tel.: +45 45252131. E-mail: mhc@kemi.dtu.dk 


\begin{abstract}
Griseofulvin (1) is an important antifungal agent that has recently received attention due to its antiproliferative activity in mammalian cancer cells. Comprehensive SAR studies have led to the identification of 2'-benzyloxy griseofulvin 2, a more potent analogue with low micromolar anticancer potency in vitro. Analogue 2 was also shown to retard tumor growth through inhibition of centrosomal clustering in murine xenograft models of colon cancer and multiple myeloma. However, similar to griseofulvin, compound $\mathbf{2}$ exhibited poor metabolic stability and aqueous solubility. In order to improve the poor pharmacokinetic properties, 11 griseofulvin analogues were synthesized and evaluated for biological activity and physiological stabilities including SGF, plasma, and metabolic stability. Finally, the most promising compounds were investigated in respect to thermodynamic solubility and formulation studies. The 2'-benzylamine analogue $\mathbf{1 0}$ proved to be the most promising compound with low $\mu \mathrm{M}$ in vitro anticancer potency, a 200-fold increase in PBS solubility over compound 2, and with improved metabolic stability. Furthermore, this analogue proved compatible with formulations suitable for both oral and intravenous administration. Finally, 2'-benzylamine analogue $\mathbf{1 0}$ was confirmed to induce G2/M cell cycle arrest in vitro.
\end{abstract}

Keywords

Griseofulvin; cancer; centrosomal clustering; pharmacokinetics; solubility; formulations

Chemical compounds studied in this article

Griseofulvin (PubChem CID: 441140) 


\section{Introduction}

Griseofulvin (1), a natural product from Penicillium griseofulvum, was first discovered in 1939 and has since 1958 been known for its antifungal properties in guinea pigs and man (Figure 1) [1-3]. Since then, more than 400 analogues have been synthesized and in more recent years the compound class has received renewed interest due to findings of anticancer effects [4-7]. Griseofulvin has been identified as a tubulin binder that disrupts tubulin polymerization and microtubule dynamics [8,9] and was in 2007 shown to inhibit centrosomal clustering in vitro [10]. While normal cells have exactly two centrosomes at the onset of mitosis, tumor cells often have supernumerary centrosomes that lead to formation of multiple spindle poles. To avoid lethal asymmetric cell divisions, cancer cells rely on a dynamic process called centrosomal clustering to form pseudo-bipolar spindles and thus ensure appropriate cell division. Consequently, inhibition of centrosomal clustering may constitute a novel therapeutic strategy in oncology, by selective eradication of cancer cells with supernumerary centrosomes [11-13].

Following this discovery, we have published three SAR studies covering more than 60 griseofulvin analogues with structural modifications to the 4, 5, 6, 2', 3', and 4' positions [14-16] that were tested against multiple cancer cell lines. The endeavor led to identification of a new griseofulvin analogue, the 2'-benzyloxy analogue 2, that exhibited a 25-fold activity increase as a centrosome clustering inhibitor compared to 1 (Figure 1). In vivo studies confirmed analogue 2 to retard tumor growth through inhibition of centrosomal clustering in murine xenograft models of colon cancer and multiple myeloma [14,17]. 

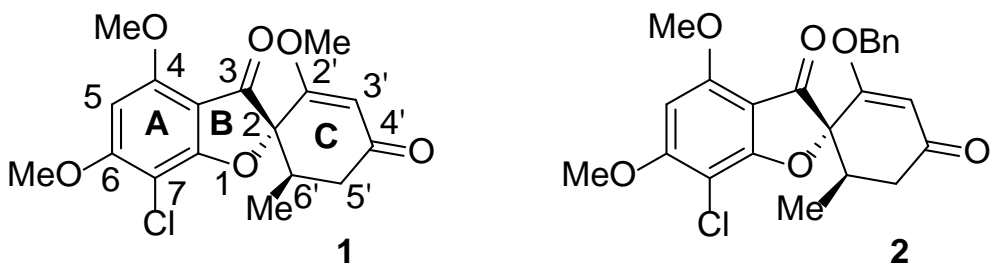

Figure 1. Chemical structure of griseofulvin (1) with IUPAC recommended numbering and ring designation and the 2'-benzyloxy griseofulvin analogue 2 .

While griseofulvin analogues show potential as small molecule therapeutics in cancer treatment, the compounds generally suffer from poor pharmacokinetic properties including low solubility and metabolic instability $[16,18]$. In order to further our studies of griseofulvin derivatives, we herein report the synthesis and biological evaluation of 11 griseofulvin analogues (6 reported for the first time) with different 2'-substitution patterns. In addition to biological activity, griseofulvin (1) and analogues hereof were also subjected to pharmacokinetic studies involving stability in simulated gastric fluid (SGF) and plasma, plasma protein binding (PPB) as well as metabolic stability. Finally, thermodynamic solubility in phosphate buffered saline (PBS) and formulation studies were performed on the most promising analogues.

\section{Results and Discussion}

\subsection{Synthesis}

The strategy used for preparation of the griseofulvin analogues was first described by Stephenson and co-workers [19] and later modified by Rønnest and colleagues (Scheme 1) [14,15]. Griseofulvin (1) was hydrolyzed to griseofulvic acid (3) and then converted into the 2'-chloro 
derivative 4 with phosphoryl chloride and lithium chloride in 1,4-dioxane. 2'-Chloro griseofulvin 4 was treated with a suitable amine or alcohol nucleophile $(\mathrm{RH})$ in the presence of 1,8diazabicycloundec-7-ene (DBU) to yield the desired product with the general structure 5.<smiles>COc1cc(OC)c2c(c1Cl)O[C@@]1(Oc3c(Cl)c(OC)cc(OC)c3C(C)=CC(=O)C1=O)C2=O</smiles><smiles>[R]C1=CC(=O)CC(C)[C@]12Oc1c(OC)c(OC)cc(OC)c1C2=O</smiles>

Scheme 1. Overview of the synthetic strategy used for preparation of the 2'-modified griseofulvin analogues with the general structure $\mathbf{5}$.

\subsection{Compounds}

In our previously reported SAR studies, multiple 2'-oxy modified griseofulvin analogues were synthesized and evaluated. Here, a series of para-substituted 2'-benzyloxy analogues as well as the 4'-oxime of 2 were found to have activity similar to compound $2[14,15]$. For this reason, the 2'-(4methylbenzyloxy) analogue $\mathbf{6}$, the 2'-(4-fluorobenzyloxy) analogue $\mathbf{7}$, the 2'-(4-

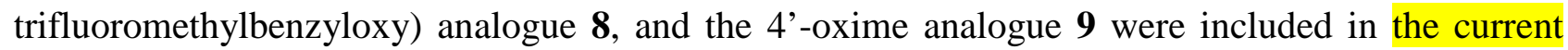
study (Figure 2). 
<smiles>COc1cc(OC)c(C(=O)OC2=CC(=O)CC(C)C23Oc2c(Cl)cc(C)cc2Cc2ccc(C)cc23)c(OC)c1</smiles><smiles>[Z]C1CC(=O)C=C(OCc2ccc(C(F)(F)F)cc2)[C@]12COc1c(Cl)c(OC)cc(OC)c1C2=O</smiles><smiles></smiles><smiles>COc1cc(OC)c(C(=O)C2=CC(=N)C=CC2C(=O)O)c(OC)c1Cl</smiles>

Figure 2. Previously reported 2'-oxy modified griseofulvin analogues with antiproliferative activity comparable to compound 2.

In addition to these previously synthesized inhibitors, six new analogues were prepared. To examine the importance of the 2'-heteroatom and potentially enhance solubility, a similar series of 2'-amino modified analogues, 10-12, was synthesized. Furthermore, as all previously reported 2'benzyloxy analogues have contained an unbranched linker, the 2'-tertiary amino analogue $\mathbf{1 3}$ as well as the two 2'-phenethyl modified analogues, 14 and 15, were also prepared (Figure 3). In total, 12 compounds consisting of griseofulvin (1), five previously reported 2'-oxy modified analogues (6-9), and six new analogues (10-15), were investigated.
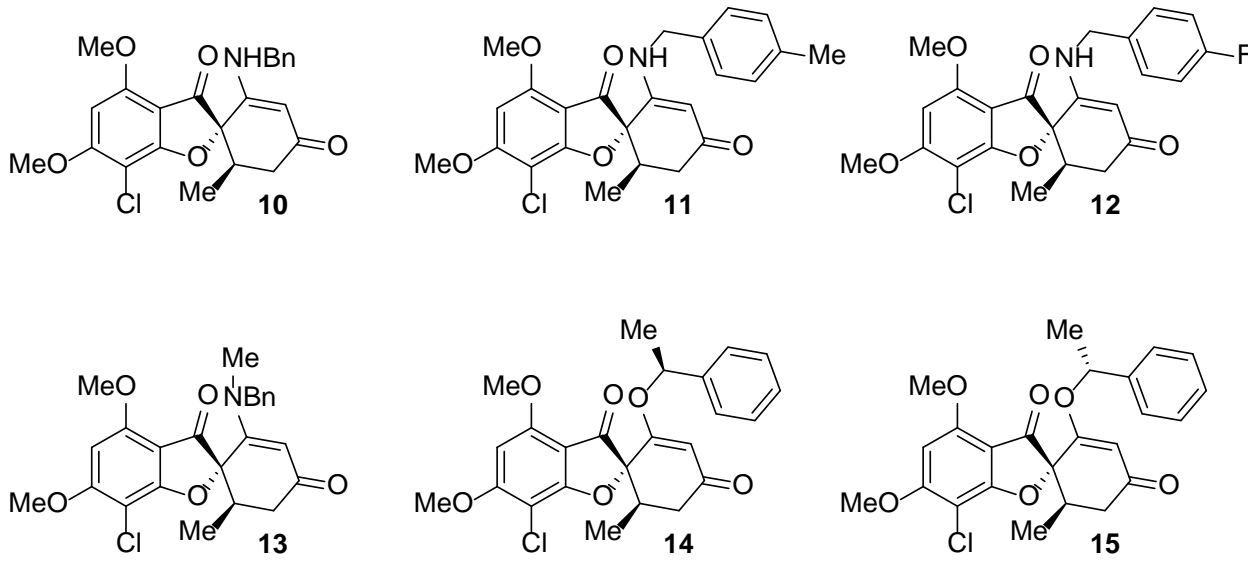
Figure 3. The four 2'-amino analogues 10-13 and two 2'-phenethyl modified compounds 14 and 15.

\subsection{Biological evaluation}

The activity of 1 was measured as $25.0 \pm 4.9 \mu \mathrm{M}$ and $22.4 \pm 5.4 \mu \mathrm{M}$ against the human epithelial cancer cell line MDA-MB-231 and the human osteosarcoma cancer cell line U2OS, respectively. As evident from Table 1, all tested analogues exhibited improved biological activity compared to $\mathbf{1}$ against both cancer cell lines. The previously reported analogues 2, 6, and 9 and the two new 2'amino modified analogues $\mathbf{1 0}$ and $\mathbf{1 3}$ were the most potent and showed an approximate 10-fold increase in activity over 1. Except for 6, para-substitution on the 2'-aryl moiety led to a decrease in activity. Both 2'-oxy linker modified analogues $\mathbf{1 4}$ and $\mathbf{1 5}$ displayed a decrease in activity compared to 2 . As the additional methyl group in these compounds would likely decrease aqueous solubility, 14 and $\mathbf{1 5}$ were not included in the following pharmacokinetic studies.

Table 1. Anticancer activity of griseofulvin and analogues against two human cancer cell lines.

\begin{tabular}{lcc}
\hline Compound & MDA-MB-231 & U2OS \\
& IC50 $(\boldsymbol{\mu M})$ & IC50 $(\boldsymbol{\mu M})$ \\
\hline $\mathbf{1}$ & $25.0 \pm 4.9$ & $22.4 \pm 5.4$ \\
\hline $\mathbf{2}$ & $1.7 \pm 0.2$ & $1.3 \pm 0.3$ \\
\hline $\mathbf{6}$ & $1.7 \pm 0.2$ & $1.3 \pm 0.3$ \\
\hline $\mathbf{7}$ & $3.3 \pm 1.6$ & $2.6 \pm 0.2$ \\
\hline $\mathbf{8}$ & $6.6 \pm 1.5$ & $5.6 \pm 1.1$ \\
\hline $\mathbf{9}$ & $1.4 \pm 0.4$ & $1.2 \pm 0.1$ \\
\hline
\end{tabular}




\begin{tabular}{lcc}
\hline $\mathbf{1 0}$ & $3.2 \pm 1.0$ & $2.1 \pm 0.1$ \\
\hline $\mathbf{1 1}$ & $8.2 \pm 1.8$ & $6.9 \pm 0.4$ \\
\hline $\mathbf{1 2}$ & $5.2 \pm 2.4$ & $2.6 \pm 0.3$ \\
\hline $\mathbf{1 3}$ & $3.5 \pm 1.6$ & $1.9 \pm 0.4$ \\
\hline $\mathbf{1 4}$ & $7.1 \pm 1.1$ & $1.6 \pm 0.2$ \\
\hline $\mathbf{1 5}$ & $17.1 \pm 5.0$ & $13.7 \pm 2.2$ \\
\hline
\end{tabular}

\subsection{Plasma stability}

Variations within $\pm 20 \%$ is considered within the uncertainty of this assay and the numbers indicate high stability. Thus, $\mathbf{1}$ and all tested analogues exhibited excellent stability in both rat and mouse plasma (Table 2) with values ranging from 87 to $117 \%$.

\subsection{Simulated gastric fluid stability}

To identify acid sensitive compounds that would be incompatible with oral administration, the analogues were subjected to a SGF stability assay (Table 2). SGF was designed to mimic the fasted stomach and contained $\mathrm{HCl}, \mathrm{NaCl}$, and pepsin at $\mathrm{pH}$ 1.2. The 2'-oxy modified analogues, 2 and 6-9, generally showed SGF stability similar to $\mathbf{1}$. The 2'-amino modified analogues $\mathbf{1 0 - 1 2}$ exhibited slightly lower stability compared to the 2'-oxy analogues. Interestingly, $\mathbf{1 3}$ proved highly unstable in SGF with only 15\% of the parent compound remaining after $2 \mathrm{~h}$.

\subsection{Metabolic stability}


Metabolic stability was evaluated using liver microsomes from mice and rats and determined as intrinsic clearance (CLint). As evident from SGF stabilities, the 2'-benzylmethylamine $\mathbf{1 3}$ was significantly less stable against metabolic degradation compared to the other compounds tested. This is likely attributed to easier protonation and/or cleavage of the 2'-tertiary amino substituent compared to the secondary amine- and oxy-substituents. In contrast to the trend observed for SGF stability, exchange of the 2'-enol moiety for the corresponding enamine generally increased metabolic stability against both rat and mouse microsomes. Most interesting was the potent 2'amino analogue $\mathbf{1 0}$ that showed a 2- and 4-fold increase in metabolic stability against rat and mice liver microsomes, respectively. This is likely explained by the increased hydrophilicity of $\mathbf{1 0 - 1 2}$ (vide infra). The results also revealed that the aromatic moiety introduced at the 2'-position was not a metabolic hotspot as both plasma and metabolic stabilities of the griseofulvin derivatives (compounds 2-12) were comparable to the parent drug 1.

\subsection{Plasma protein binding}

Griseofulvin (1) was shown to have medium PPB with a percentage of fraction unbound (\% $\mathrm{f}_{\mathrm{u}}$ ) calculated to $22 \%$ and $43 \%$ in rat and mouse, respectively. While all analogues showed higher PPB than 1, the 2'-oxy modified compounds generally showed the highest PPB.

Table 2. Pharmacokinetic data on compounds 1-13.

\begin{tabular}{|c|c|c|c|c|c|c|c|}
\hline \multirow[t]{2}{*}{ Cmp } & \multicolumn{3}{|c|}{$\begin{array}{c}\text { Biological stability (\% compound } \\
\text { remaining after } 120 \mathrm{~min} \text { ) }\end{array}$} & \multicolumn{2}{|c|}{$\begin{array}{c}\text { Metabolic stability } \\
\text { CLint (mL/min/mg protein) }\end{array}$} & \multicolumn{2}{|c|}{ PPB $\left(\% f_{u}\right)$} \\
\hline & Rat plasma & Mouse plasma & SGF & Rat & Mouse & Rat plasma & Mouse plasma \\
\hline 1 & 107 & 107 & 73 & $56.6 \pm 2.1$ & $135 \pm 1$ & $21.6 \pm 1.6$ & $42.7 \pm 2.0$ \\
\hline 2 & 101 & 91 & 62 & $45.0 \pm 3.8$ & $120 \pm 9$ & $2.7 \pm 0.1$ & $11.2 \pm 2.8$ \\
\hline
\end{tabular}




\begin{tabular}{cccccccc}
\hline $\mathbf{6}$ & 89 & 102 & 68 & $60.2 \pm 3.2$ & $67.0 \pm 4.0$ & $1.8 \pm 0.7$ & $1.8 \pm 0.4$ \\
\hline $\mathbf{7}$ & 109 & 102 & 62 & $44.9 \pm 1.0$ & $81.7 \pm 3.1$ & $2.2 \pm 0.1$ & $2.9 \pm 0.5$ \\
\hline $\mathbf{8}$ & 108 & 92 & 75 & $30.7 \pm 2.1$ & $17.4 \pm 1.2$ & $1.1 \pm 0.1$ & $2.5 \pm 0.3$ \\
\hline $\mathbf{9}$ & 102 & 87 & 81 & $59.1 \pm 4.2$ & $104 \pm 2$ & $1.4 \pm 0.1$ & $4.3 \pm 2.8$ \\
\hline $\mathbf{1 0}$ & 116 & 117 & 52 & $28.0 \pm 1.72$ & $33.7 \pm 1.1$ & $11.1 \pm 0.3$ & $14.1 \pm 1.7$ \\
\hline $\mathbf{1 1}$ & 111 & 107 & 54 & $25.2 \pm 2.6$ & $47.4 \pm 1.6$ & $5.5 \pm 0.1$ & $11.0 \pm 0.2$ \\
\hline $\mathbf{1 2}$ & 92 & 108 & 54 & $25.5 \pm 2.4$ & $40.8 \pm 2.2$ & $9.4 \pm 0.2$ & $13.2 \pm 0.1$ \\
\hline $\mathbf{1 3}$ & 106 & 104 & 15 & $268 \pm 14$ & $358 \pm 41.6$ & $6.0 \pm 0.6$ & $8.7 \pm 0.7$
\end{tabular}

SGF = simulated gastric fluid; $\mathrm{CL}_{\mathrm{int}}=$ intrinsic clearance; $\mathrm{PPB}=$ plasma protein binding; $\mathrm{f}_{\mathrm{u}}=$ fraction unbound.

\subsection{Thermodynamic solubility}

On the basis of activity and biologic stability results, thermodynamic solubility in PBS buffer was determined for the most promising analogues, 2, 9, and 10. While the 2'-oxy compounds $\mathbf{6}$ and $\mathbf{7}$ showed similar activity and pharmacokinetic properties, the hydrophobicity constants of the methyl and trifluoromethyl group are both positive compared to hydrogen and were expected to result in poorer aqueous solubility than $\mathbf{2}$. The approved drug griseofulvin (1) is known to have poor aqueous solubility [18] and improving solubility is therefore of high importance. The solubility of 1 (7.7 $\mu \mathrm{g} / \mathrm{mL}$ ) measured in PBS buffer at $22{ }^{\circ} \mathrm{C}$ is in agreement with earlier reported values measured in water at temperatures between $15{ }^{\circ} \mathrm{C}$ and $30{ }^{\circ} \mathrm{C}$ [20]. With $\mathbf{1}$ as reference, 2 and $\mathbf{9}$ had PBS solubility approximately 25- and 2.5-fold lower, respectively, whereas 10 exhibited roughly a 10fold improvement in solubility over $\mathbf{1}$ (Table 3). As expected, introduction of the secondary amine in $\mathbf{1 0}$ increased PBS solubility significantly. Table 3 also shows that there is no correlation between the thermodynamic solubility and clogP. As 9 is an isomeric mixture of $E$ and $Z$ oxime isomers, the thermodynamic solubility was calculated from the total chromatogram peak areas of the two 
isomers. The ratios between the minor and major isomers were 1:1.8 in acetonitrile and 1:1.6 in PBS buffer, as measured by HPLC, and 1:1.5 in $\mathrm{CDCl}_{3}$, as measured by ${ }^{1} \mathrm{H}$ NMR.

Table 3. Thermodynamic solubility and clogP of $\mathbf{1}$ and the most promising analogues, compounds 2, 9, and 10 .

\begin{tabular}{ccc}
\hline Compound & $\begin{array}{c}\text { Thermodynamic solubility } \\
(\boldsymbol{\mu g} / \mathbf{m L})\end{array}$ & $\operatorname{clogP}^{\boldsymbol{a}}$ \\
\hline $\mathbf{1}$ & 7.7 & 2.17 \\
\hline $\mathbf{2}$ & 0.3 & 3.90 \\
\hline $\mathbf{9}$ & 3.0 & 3.91 \\
\hline $\mathbf{1 0}$ & 62 & 3.58
\end{tabular}

${ }^{a}$ cLogP partition coefficient was calculated according to Viswanadhan et al. [21] using Chemicalize software by ChemAxon.

\subsection{Formulation experiments for dosage delivery in clinical trials}

For investigation of dosage delivery for in vivo experiments, a series of formulation experiments were also performed on the three analogues $\mathbf{2 , 9}$, and $\mathbf{1 0}$. For oral/gastrointestinal delivery (“oral formulation”), viscous liquid polyethylene glycol (PEG) 400 and solid matrix PEG8000 dosage forms were studied. PEG400 and PEG8000 can be further processed into final pharmaceutical products such as tablets/capsules and were designed with an active pharmaceutical ingredient (API) concentration of $5 \mathrm{mg} / \mathrm{mL}$. For intravenous infusion (“IV solution”), a "water for injection” (WFI) dosage solution consisting of polysorbate 80 and poloxamer 188 (both at $5 \mathrm{mg} / \mathrm{mL}$ ) was chosen. 
The WFI solution contained API at $1 \mathrm{mg} / \mathrm{mL}$. The stability of the griseofulvin analogues in the different dosage forms at both 5 and $25^{\circ} \mathrm{C}$ were measured by HPLC over a period of 30 days (Table 4).

Although 10\% PEG400 was needed for dissolution of 2 in PEG8000, all three analogues were easily dissolved and remained stable in low and high molecular weight PEG at both 5 and $25{ }^{\circ} \mathrm{C}$. Analogues $\mathbf{2}$ and $\mathbf{1 0}$ were easily solubilized in water (WFI) when applying a mixture of polysorbate 80 and poloxamer 188 surfactants. At $5{ }^{\circ} \mathrm{C}$, both analogues showed no signs of degradation, however, at $25{ }^{\circ} \mathrm{C}$ only 9 remained stable. Due to the low aqueous solubility of 2 , work on this compound was challenging and resulted in an unstable dosage form. The use of corn oil as an oral absorption enhancer was also investigated. However, these experiments proved unsuccessful as sedimentation formed in all three solutions upon cooling after dissolution at elevated temperatures.

Table 4. Stability study of analogues 2, 9, and $\mathbf{1 0}$ in three different types of dosage forms. Positive (+) stabilities were assigned when the compounds did not show signs of degradation in their respective chromatograms after 30 days at the described conditions. The concentration of API was 5 mg/mL for PEG400 and PEG8000 and $1 \mathrm{mg} / \mathrm{mL}$ liquid WFI, unless otherwise stated.

\begin{tabular}{cccc}
\hline Cmp & Liquid PEG400 stability & Solid PEG8000 stability & Liquid WFI stability \\
& $\left(\mathbf{5} / \mathbf{2 5}{ }^{\circ} \mathbf{C}\right)$ & $\left(\mathbf{5} / \mathbf{2 5}{ }^{\circ} \mathbf{C}\right)$ & $\left(\mathbf{5} / \mathbf{2 5}{ }^{\circ} \mathbf{C}\right)$ \\
\hline $\mathbf{2}$ & $+^{a} /+^{a}$ & $+^{b /+^{b, c}}$ & $-/-$ \\
\hline $\mathbf{9}$ & $+/+$ & $+/+$ & $+/+$ \\
\hline $\mathbf{1 0}$ & $+/+$ & $+/+$ & $+/-$
\end{tabular}

${ }^{a}$ API $10 \mathrm{mg} / \mathrm{mL}$; ${ }^{b}$ contains $10 \%$ PEG 400; ${ }^{c} 4 \%$ degradation detected after 33 days; PEG: polyethylene glycol; WFI = water for injection. 


\subsection{Cell cycle analysis}

With 10 exhibiting the most promising combination of potency and physico-chemical properties, this analogue was subjected to a cell cycle analysis to investigate if its mechanism of action was similar to griseofulvin. Both $\mathbf{1}$ and $\mathbf{2}$ have previously been confirmed to exhibit antiproliferative effect on human cancer cells and to cause G2/M arrest [10,17]. Cell cycle analysis of U2OS cells treated with $\mathbf{1}$ or $\mathbf{1 0}$ was performed by flow cytometry using propidium iodide staining. As evident from Figure 4, 1 and $\mathbf{1 0}$ both induced G2/M arrest in a concentration dependent manner. In agreement with the anticancer activity against U2OS (Table 1), analogue $\mathbf{1 0}$ exhibited more than a 10-fold increase in potency over 1. Based on these findings and as expected, we conclude that analogue $\mathbf{1 0}$ works by a similar mechanism of action as $\mathbf{1}$ and $\mathbf{2}$. Indeed, this is of little surprise since $\mathbf{2}$ and $\mathbf{1 0}$ are structurally highly similar (only the 2'-oxygen has been exchanged for an $\mathrm{NH}$ ). 

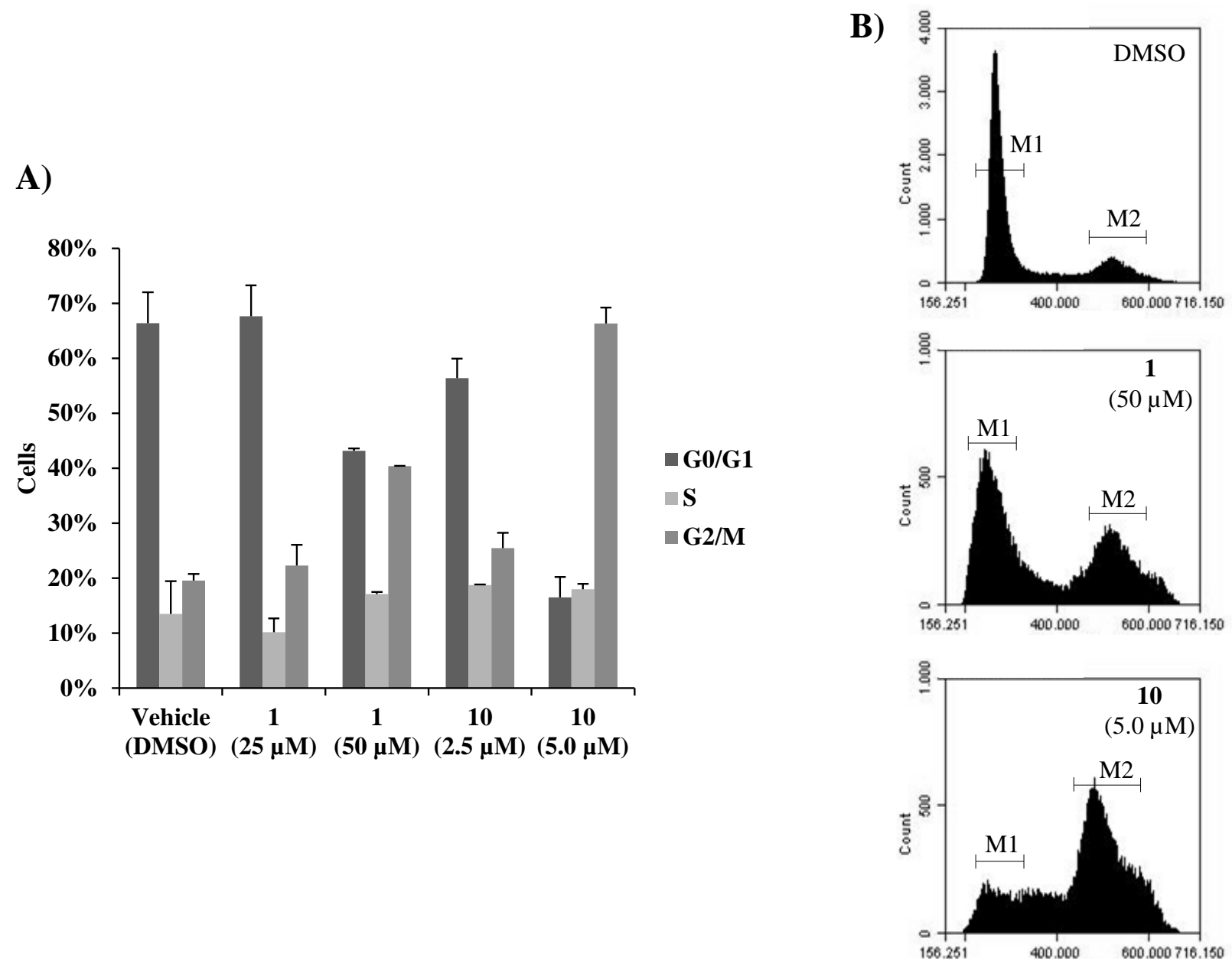

Figure 4: Cell cycle analysis of exponentially growing U2OS cells treated with griseofulvin (1), analogue 10, or vehicle (DMSO) for 24 hours. A) Cell cycle distribution showing the percentages of cells in G0/G1, S, and G2/M phases. Bars indicate averages \pm SD from two independent experiments. B) Examples of representative cell cycle histograms based on gated propidium iodide staining. Bars indicate cell populations in the G0/G1 (M1) and G2/M (M2) phases, respectively.

\section{Conclusion}


Based on our earlier studies on the anticancer properties of griseofulvin (1) and analogues, six new analogues were synthesized and evaluated along with four of our previously reported 2'-oxy modified analogues $[14,15]$. The most potent compounds against the cancer cell lines MDA-MB231 and U2OS were $\mathbf{2}, \mathbf{6 ,} \mathbf{7 , 9}, \mathbf{1 0}$, and $\mathbf{1 3}$ with $\mathrm{IC}_{50}$-values ranging from $1-3 \mu \mathrm{M}$, an approximate 10 -fold increase in activity over $\mathbf{1}$. Increasing the bulkiness of the 2'-oxy linker of 2 resulted in decreased activity against the cancer cell lines as evident from the 2'-phenethyl compounds 14 and 15. With the exception of the 2'-tertiary amine 13, pharmacokinetic evaluation of the analogues indicated acceptable biological and metabolic stabilities of all compounds. The three most promising analogues, 2, 9, and 10, were further subjected to thermodynamic solubility- and formulation studies. Thermodynamic solubilities in PBS were determined to $0.3,3$, and $62 \mu \mathrm{g} / \mathrm{mL}$ for compounds 2, 9, and 10, respectively. When comparing these values to griseofulvin (1), an approved drug with a low PBS solubility of $7.7 \mu \mathrm{g} / \mathrm{mL}, 10$ stood out as a promising analogue. Furthermore, the three compounds were investigated in formulation experiments for oral/gastrointestinal delivery and intravenous infusion. While all analogues were soluble and stable in the oral PEG400 or PEG8000 formulations, only $\mathbf{9}$ and $\mathbf{1 0}$ was compatible with a WFI solution for intravenous infusion.

Based on the biological and physico-chemical data obtained, the new 2'-benzylamine analogue 10 has proven the most promising lead for future SAR studies. Compared to $\mathbf{1}$, analogue $\mathbf{1 0}$ exhibited a 20-fold increase in biological activity with $\mathrm{IC}_{50}=3.2 \pm 1.0 \mu \mathrm{M}$ and $2.1 \pm 0.1 \mu \mathrm{M}$ against the MDAMB-231 and U2OS cancer cell lines, respectively. Furthermore, 10 exhibited good SGF, plasma, and metabolic stabilities with the latter being several folds better than for $\mathbf{1}$. Finally, analogue $\mathbf{1 0}$ was confirmed to exert its anticancer effects through induction of G2/M cell cycle arrest in vitro as has previously been documented for both $\mathbf{1}$ and $\mathbf{2}$. 
For future studies, it should be worth considering the incorporation of an oxime moiety into analogue $\mathbf{1 0}$ for an additional boost to aqueous solubility. As oxime $\mathbf{9}$ exhibited a 10-fold increase in PBS solubility compared to compound 2 without loss of potency, this presents an attractive modification to pursue.

\section{$4 \quad$ Materials and methods}

\subsection{Chemistry}

Starting materials, reagents, and solvents were purchased from Sigma-Aldrich and used without further purification, unless otherwise noted. All solvents were of analytical grade and dried when necessary over $4 \AA$ activated molecular sieves and water content was determined to be less than 20 ppm by Karl Fischer titration on a Metrohm 899 - Coulometer. For reactions carried out under argon the glassware was dried before use, employing the following procedure: heating was applied with a heat gun while the glassware was evacuated (16 Torr), the evacuation was followed by argon flushing. Evacuation and flushing were applied several times under continuous heating, and finally the glassware was allowed to cool to room temperature under argon before use. Thin Layer Chromatography (TLC) was carried out on commercially available pre-coated plates (Merck 60, F254). Dry Column Vacuum Chromatography (DCVC) was performed according to a published procedure[22]. When concentrating on celite in vacuo for DCVC purification, high vacuum was also used.

${ }^{1} \mathrm{H},{ }^{13} \mathrm{C}$, HSQC, HMBC NMR spectra were recorded on a Bruker Ascend 400 Fourier transform spectrometer using an internal deuterium lock. ${ }^{19} \mathrm{~F}$ NMR Spectra were recorded on a Varian 
Mercury 300 B Fourier transform spectrometer. Solvents were used as internal standards when assigning ${ }^{1} \mathrm{H}$ and ${ }^{13} \mathrm{C}$ NMR spectra $\left(\delta \mathrm{H}: \mathrm{CHCl}_{3} 7.26\right.$ ppm, DMSO- $d_{5} 2.50 ; \delta \mathrm{C}: \mathrm{CDCl}_{3} 77.16 \mathrm{ppm}$, DMSO- $d_{6} 39.52$ ppm). HRMS was performed on a Bruker Daltronics maXis 3G QTOF-MS fitted with a Dionex Ultimate 3000 UHPLC. A Stuart Advanced Digital Melting Point SMP30 was used to determine melting point and they are reported uncorrected. Optical rotation was measured on a Perkin-Elmer 241 Polarimeter, and the values are given in degrees and concentrations are given in $\mathrm{g} / 100 \mathrm{~mL}$.

\subsection{Synthesis}

Compounds 2, 6, 7, 8, and $\mathbf{9}$ were prepared according to literature procedures.[14,15]

\subsection{1 (2S,6'R)-2'-(Benzylamino)-7-chloro-4,6-dimethoxy-6'-methyl-3H-spiro[benzofuran-2,1'-} cyclohexan]-2'-ene-3,4'-dione (10)

To a stirred solution of 4 (1.07 $\mathrm{g}, 3 \mathrm{mmol})$ under argon in 1,4-dioxane (15 ml) was added benzylamine (0.66 ml, $6 \mathrm{mmol})$ followed by DBU $(1.16 \mathrm{ml}, 7.5 \mathrm{mmol})$. The solution was heated at $50{ }^{\circ} \mathrm{C}$ for $21 \mathrm{~h}$, and $95{ }^{\circ} \mathrm{C}$ for additional $45 \mathrm{~min}$. The mixture was allowed to reach $22{ }^{\circ} \mathrm{C}$, concentrated on celite and purified by DCVC: $(\varnothing=40 \mathrm{~mm})$ gradient eluted with 99:1 toluene:Et ${ }_{3} \mathrm{~N}$ $\rightarrow$ 81:18:1 toluene:MeCN:Et $3 \mathrm{~N} 2 \%$ increment/50 mL fraction). The resulting light yellow solid was recrystallized from THF/heptane yielding $100.91 \mathrm{~g}(71 \%)$ as light yellow crystals. $R_{\mathrm{f}}=0.13$ (85:10:5 toluene:MeCN:Et 3 ); mp: $130-132{ }^{\circ} \mathrm{C} ;[\alpha]_{D}^{20}=+392^{\circ}\left(\mathrm{c}=1.0\right.$ in $\left.\mathrm{CHCl}_{3}\right) ;{ }^{1} \mathrm{H}$ NMR $(400$ $\left.\mathrm{MHz}, \mathrm{CDCl}_{3}\right): \delta$ 7.36-7.22 (m, 3H), $7.16(\mathrm{~d}, J=6.9 \mathrm{~Hz}, 2 \mathrm{H}), 6.16(\mathrm{~s}, 1 \mathrm{H}), 5.28(\mathrm{~s}, 1 \mathrm{H}), 4.91(\mathrm{t}, J=$ $5.2 \mathrm{~Hz}, 1 \mathrm{H}), 4.16$ (ABX, $J=24.0,16.0 \mathrm{~Hz}, \Delta=17.9 \mathrm{~Hz}, 2 \mathrm{H}), 4.01(\mathrm{~s}, 3 \mathrm{H}), 3.97$ (s, 3H), 2.97- 2.82 
(m, 2H), 2.41-2.28 (m, 1H), 0.93-0.86 (d, $J=6.0 \mathrm{~Hz}, 3 \mathrm{H}) ;{ }^{13} \mathrm{C}$ NMR (101 MHz, CDCl $): \delta 195.2$, 191.4, 168.3, 164.7, 158.0, 157.4, 136.2, 129.0 (2C), 128.0, 127.4 (2C), 104.7, 99.8, 97.4, 91.7, 90.4, 57.2, 56.6, 47.3, 39.1, 37.4, 14.7; HRMS (ESI $\left.{ }^{+}\right) 428.1279$ calcd. for $[\mathrm{M}+\mathrm{H}]^{+} 428.1259$.

\subsection{2 (2S,6'R)-7-Chloro-4,6-dimethoxy-6'-methyl-2'-((4-methylbenzyl)amino)-3H-}

spiro[benzofuran-2,1'-cyclohexan]-2'-ene-3,4'-dione (11)

4-Methylbenzylamine (0.13 mL, $1 \mathrm{mmol})$ and DBU (0.19 mL, $1.25 \mathrm{mmol})$ was added to a stirred solution of $4(0.18 \mathrm{~g}, 0.5 \mathrm{mmol})$ in dry 1,4-dioxane $(2.5 \mathrm{~mL})$. After heating to $80{ }^{\circ} \mathrm{C}$ for $15 \mathrm{~h}$, the mixture was allowed to reach $22{ }^{\circ} \mathrm{C}$ and evaporated in vacuo resulting in a light brow gum. The residue was purified by flash column chromatography using eluent gradient $\mathrm{MeCN} / \mathrm{CH}_{2} \mathrm{Cl}_{2}$ (3:7;

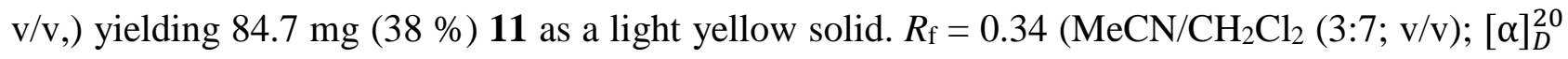
$=+410^{\circ}\left(c=0.50\right.$ in $\left.\mathrm{CHCl}_{3}\right) ;{ }^{1} \mathrm{H}$ NMR $\left(400 \mathrm{MHz} \mathrm{CDCl}_{3}\right) \delta 7.11(\mathrm{~d}, J=8.0 \mathrm{~Hz}, 2 \mathrm{H}), 7.06(\mathrm{~d}, J=$ $8.1 \mathrm{~Hz}, 2 \mathrm{H}), 6.15$ (s, 1H), $5.29(\mathrm{~s}, 1 \mathrm{H}), 4.84(\mathrm{t}, J=5.1 \mathrm{~Hz}, 1 \mathrm{H}), 4.11(\mathrm{ABX}, J=14.6,5.2 \mathrm{~Hz}, \Delta=$ $21.3 \mathrm{~Hz}, 2 \mathrm{H}), 4.01$ (s, 3H), 3.97 (s, 3H), 2.96-2.84 (m, 2H), 2.38-2.32 (m, 1H), 0.89 (d, $J=6.3 \mathrm{~Hz}$, 3H); ${ }^{13} \mathrm{C}$ NMR (101 MHz, $\left.\mathrm{CDCl}_{3}\right) \delta 195.5,191.4,168.2,164.7,158.0,157.4,137.8,133.1,129.7$, 127.5, 104.7, 99.7, 97.4, 91.7, 90.4, 57.2, 56.6, 47.2, 39.1, 37.4, 21.2, 14.7; HRMS (ESI+) 442.1422 calcd. for $[\mathrm{M}+\mathrm{H}]^{+} 442.1416$.

\subsection{3 (2S,6'R)-7-Chloro-2'-((4-fluorobenzyl)amino)-4,6-dimethoxy-6'-methyl-3H-}

spiro[benzofuran-2,1'-cyclohexan]-2'-ene-3,4'-dione (12)

To a stirred solution of 4 (0.36 g, $1 \mathrm{mmol})$ under argon in 1,4-dioxane (5 mL) was added 4fluorobenzylamine $(0.23 \mathrm{~mL}, 2 \mathrm{mmol})$ followed by DBU $(0.37 \mathrm{~mL}, 2.5 \mathrm{mmol})$. The solution was 
stirred for $6 \mathrm{~h}$ at $95{ }^{\circ} \mathrm{C}$ before cooling it to $22{ }^{\circ} \mathrm{C}$ and concentrating it on celite in vacuo. Purification by DCVC $(\varnothing=20 \mathrm{~mm}$ ) gradient eluted 100 toluene $\rightarrow 62.5: 37.5$ toluene:MeCN 2.5\% increment/20 mL fraction (all solvents containing $1 \% \mathrm{Et}_{3} \mathrm{~N}$ ) yielded a white solid which was recrystallized from EtOAc/heptane resulting in $0.11 \mathrm{~g}$ (22\%) 12 as white crystals. $R_{\mathrm{f}}=0.16$ (70:28:2 toluene:MeCN:Et $3 \mathrm{~N}) ; \mathrm{mp}: \quad 161-163{ }^{\circ} \mathrm{C} ;[\alpha]_{D}^{20}=+378^{\circ}\left(c=0.43, \mathrm{CHCl}_{3}\right) ;{ }^{1} \mathrm{H}$ NMR $(400 \mathrm{MHz}$, $\left.\mathrm{CDCl}_{3}\right) \delta 7.13(\mathrm{dd}, J=8.5,5.4 \mathrm{~Hz}, 2 \mathrm{H}), 6.98(\mathrm{t}, J=8.6 \mathrm{~Hz}, 2 \mathrm{H}), 6.16$ (s, 1H), 5.24 (s, 1H), 4.90 (s, 1H), 4.20-4.06 (m, 2H), 4.02 (s, 3H), 3.98 (s, 3H), 2.96-2.79 (m, 2H), 2.44-2.24 (m, 1H), 0.89 (d, $J$ $=6.2 \mathrm{~Hz}, 3 \mathrm{H}) ;{ }^{13} \mathrm{C}$ NMR $\left(101 \mathrm{MHz}, \mathrm{CDCl}_{3}\right) \delta 195.6,191.6,168.4,165.0,162.6\left(\mathrm{~d},{ }^{1} J_{\mathrm{CF}}=246.4\right.$ $\mathrm{Hz}$ ), 158.2, 157.5, 132.1 (d, $\left.{ }^{4} J_{\mathrm{CF}}=3.2 \mathrm{~Hz}\right), 129.2\left(2 \mathrm{C}, \mathrm{d},{ }^{3} J_{\mathrm{CF}}=8.2 \mathrm{~Hz}\right), 116.2\left(2 \mathrm{C}, \mathrm{d},{ }^{2} J_{\mathrm{CF}}=21.6\right.$ $\mathrm{Hz}), 104.9,100.2,97.6,91.9,90.6,57.4,56.8,46.8,39.3,37.6,14.9 ;{ }^{19} \mathrm{~F} \mathrm{NMR}\left(282 \mathrm{MHz}, \mathrm{CDCl}_{3}\right) \delta$ -114.7; HRMS $\left(\mathrm{ESI}^{+}\right.$) found 446.1167 calcd. for $[\mathrm{M}+\mathrm{H}]^{+} 446.1165$.

\subsection{4 (2S,6'R)-2'-(Benzyl(methyl)amino)-7-chloro-4,6-dimethoxy-6'-methyl-3H-spiro[benzofuran-} 2,1'-cyclohexan]-2'-ene-3,4'-dione (13)

To a stirred solution of $4(0.18 \mathrm{~g}, 0.5 \mathrm{mmol})$ and 1,8-bis(dimethylamino)naphthalene, $N, N, N^{\prime}, N^{\prime}-$ tetramethyl-1,8-naphthalenediamine (Proton-sponge) (0.27 g, $1.25 \mathrm{mmol})$ in 1,4-dioxane (3 mL) under argon was added $N$-methyl-1-phenylmethanamine $(0.13 \mathrm{~mL}, 1 \mathrm{mmol})$. The mixture was heated to $60{ }^{\circ} \mathrm{C}$ for $20 \mathrm{~h}$ and then at $85{ }^{\circ} \mathrm{C}$ for $20 \mathrm{~h}$. The reaction was allowed to reach $22{ }^{\circ} \mathrm{C}$ and the solvent was evaporated in vacuo. The resulting brown gum was purified by flash column chromatography using MeCN: $\mathrm{CH}_{2} \mathrm{Cl}_{2}$ 2:8 yielding $1350.8 \mathrm{mg}(23 \%)$ as a white solid. $R_{\mathrm{f}}=0.36$ $\left(\mathrm{MeCN}: \mathrm{CH}_{2} \mathrm{Cl}_{2} 2: 8\right) ;[\alpha]_{D}^{20}=+100^{\circ}\left(c=0.5\right.$ in $\left.\mathrm{CHCl}_{3}\right) ;{ }^{1} \mathrm{H}$ NMR $\left(400 \mathrm{MHz}, \mathrm{CDCl}_{3}\right) \delta$ 7.32-7.20 (m, 3H), 7.08 (d, $J=7.1 \mathrm{~Hz}, 2 \mathrm{H}), 6.10$ (s, 1H), 5.41 (s, 1H), $4.16(\mathrm{AB}, J=16.3 \mathrm{~Hz}, \Delta=43.2 \mathrm{~Hz}$, 2H), 3.99 (s, 3H), 3.97 (s, 3H), 3.04-2.93 (m, 1H), 2.84 (dd, $J=16.8,13.0 \mathrm{~Hz}, 1 \mathrm{H}), 2.71$ (s, 3H), 
2.33 (dd, $J=16.8,4.3 \mathrm{~Hz}, 1 \mathrm{H}), 0.85$ (d, $J=6.7 \mathrm{~Hz}, 3 \mathrm{H}) ;{ }^{13} \mathrm{C}$ NMR $\left(101 \mathrm{MHz}, \mathrm{CDCl}_{3}\right) \delta 195.4$, 191.7, 168.0, 164.7, 160.7, 157.7, 135.8, 128.9, 127.6, 127.0, 105.7 (2C), 92.1, 90.1, 57.2, 57.1, 56.6, 40.6, 39.6, 38.6, 15.2; HRMS (ESI $\left.{ }^{+}\right) 442.1418$ calcd. for $[\mathrm{M}+\mathrm{H}]^{+} 442.1416$.

\subsection{5 (2S,6'R)-7-Chloro-4,6-dimethoxy-6'-methyl-2'-((S)-1-phenylethoxy)-3H-spiro[benzofuran-} 2,1'-cyclohexan]-2'-ene-3,4'-dione (14)

To a stirred solution of 4 (0.36 mg, $1 \mathrm{mmol})$ in 1,4-dioxane (5 ml) under argon was added $(S)$ phenylethanol $(0.24 \mathrm{ml}, 2 \mathrm{mmol})$ followed by DBU $(0.37 \mathrm{ml}, 2.5 \mathrm{mmol})$. The solution was heated at $80{ }^{\circ} \mathrm{C}$ for $6 \frac{1}{2} \mathrm{~h}$ followed by $65{ }^{\circ} \mathrm{C}$ for additional $18 \mathrm{~h}$. More $(S)$-phenylethanol $(0.24 \mathrm{ml}, 2 \mathrm{mmol})$ was added and the mixture was heated to $85{ }^{\circ} \mathrm{C}$ for $5 \mathrm{~h}$ and $65{ }^{\circ} \mathrm{C}$ for additional $90 \mathrm{~h}$. The mixture was allowed to reach $22{ }^{\circ} \mathrm{C}$ and was concentrated on celite. Purification by DCVC: $(\varnothing=20 \mathrm{~mm})$ gradient eluted 100 toluene $\rightarrow$ 72.5:27.5 toluene:MeCN $2.5 \%$ increment/20 mL fraction yielded $0.20 \mathrm{~g}$ (45 \%) 14 off white solid. $R_{\mathrm{f}}=0.21\left(85: 15\right.$ toluene:MeCN); $[\alpha]_{D}^{20}=+224^{\circ}(c=0.51$ in $\mathrm{CHCl}_{3}$ ); ${ }^{1} \mathrm{H}$ NMR (400 MHz, $\left.\mathrm{CDCl}_{3}\right): \delta$ 7.26-7.17 (m, 3H), 7.02 (m, $\left.J=5.2,3.2 \mathrm{~Hz}, 2 \mathrm{H}\right), 6.15$ (s, 1H), 5.37 (s, 1H), 5.10 (q, $J=6.4 \mathrm{~Hz}, 1 \mathrm{H}), 4.05$ (s, 3H), 4.00 (s, 3H), 2.95 (dd, $J=16.3,13.0 \mathrm{~Hz}$, 1H), 2.82 (ddd, $J=13.0,6.6,4.4 \mathrm{~Hz}, 1 \mathrm{H}), 2.39$ (dd, $J=16.3,4.4 \mathrm{~Hz}, 1 \mathrm{H}), 1.47$ (d, $J=6.4 \mathrm{~Hz}, 3 \mathrm{H})$, 0.98 (d, $J=6.6 \mathrm{~Hz}, 3 \mathrm{H}) ;{ }^{13} \mathrm{C}$ NMR (101 MHz, $\left.\mathrm{CDCl}_{3}\right): \delta 197.3,192.3,169.8,168.6,164.5,157.9$, 140.6, 128.9 (2C), 128.1, 125.0 (2C), 107.2, 105.5, 97.3, 91.0, 89.6, 78.0, 57.1, 56.6, 40.3, 36.5, 23.8, 14.5; HRMS (ESI $\left.{ }^{+}\right) 465.1072$ calcd. for $[\mathrm{M}+\mathrm{Na}]^{+} 465.1075$.

4.2.6 (2S,6'R)-7-Chloro-4,6-dimethoxy-6'-methyl-2'-((R)-1-phenylethoxy)-3H-spiro[benzofuran2,1'-cyclohexan]-2'-ene-3,4'-dione (15) 
To a stirred solution of 4 (0.36 mg, $1 \mathrm{mmol})$ in 1,4-dioxane $(5 \mathrm{ml})$ under argon was added $(R)$ phenylethanol $(0.24 \mathrm{ml}, 2 \mathrm{mmol})$ followed by DBU $(0.37 \mathrm{ml}, 2.5 \mathrm{mmol})$. The solution was heated at $65{ }^{\circ} \mathrm{C}$ for $18 \mathrm{~h}$ followed by $80{ }^{\circ} \mathrm{C}$ for additional 4 days. The mixture was allowed to reach $22{ }^{\circ} \mathrm{C}$ and was concentrated on celite. Purification by DCVC: $(\varnothing=20 \mathrm{~mm})$ gradient eluted 100 toluene $\rightarrow$ 75:25 toluene:MeCN $2.5 \%$ increment/20 mL fraction yielded $0.13 \mathrm{~g}$ (29\%) 15 as a colorless viscous liquid. $R_{\mathrm{f}}=0.35$ (70:30 toluene:MeCN); $[\alpha]_{D}^{20}=+114^{\circ}\left(c=0.10, \mathrm{CHCl}_{3}\right) ;{ }^{1} \mathrm{H}$ NMR $(400$ $\left.\mathrm{MHz} \mathrm{CDCl}_{3}\right) \delta$ 7.38-7.20 (m, 5H), 6.17 (s, 1H), 5.42 (s, 1H), 5.11 (q, J = 6.3 Hz, 1H), 4.05 (s, 3H), 4.00 (s, 3H), 3.00 (dd, $J=16.7,13.5 \mathrm{~Hz}, 1 \mathrm{H}), 2.84-2.69$ (m, 1H), 2.34 (dd, $J=16.7,4.7 \mathrm{~Hz}, 1 \mathrm{H}$ ), 1.37 (d, $J=6.4 \mathrm{~Hz}, 3 \mathrm{H}), 0.97$ (d, $J=6.7 \mathrm{~Hz}, 3 \mathrm{H}) ;{ }^{13} \mathrm{C}$ NMR (101 MHz, $\left.\mathrm{CDCl}_{3}\right) \delta 197.1,192.8$, 169.8, 168.8, 164.6, 157.7, 140.8, 128.8, 128.0, 125.1, 106.9, 105.3, 97.2, 90.9, 89.5, 77.4, 57.1, 56.4, 39.8, 36.1, 23.4, 14.3; HRMS (ESI $\left.{ }^{+}\right) 465.1072$ calcd. for $[\mathrm{M}+\mathrm{Na}]^{+} 465.1075$.

\subsubsection{Chromatographic systems}

Purity and solubility experiments by HPLC was performed on the following systems: 1) Waters e2629 separation module fitted with a Waters 2998 PDA detector and a Waters Symmetry $3.5 \mu$ m C18 column $(4.6$ x $75 \mathrm{~mm})$ using eluents: $\mathrm{A}=$ water and $\mathrm{B}=\mathrm{MeCN}$ (both solvents containing 0.1 \% formic acid). 2) Agilent 1100 series setup with autosampler, PDA detector, and a Phenomenex Luna $3 \mu \mathrm{C} 182100$ Å column $(150 \times 4.6 \mathrm{~mm})$ using eluents: $\mathrm{A}=$ 95:5:0.1 MilliQ: MeCN:TFA and $\mathrm{B}=0.1 \%$ TFA in MeCN. In both cases, chromatograms were analyzed at $254 \mathrm{~nm}$ wavelength. Separations were performed in a total run time of 26 min under gradient conditions with a flow rate

of $1 \mathrm{~mL} / \mathrm{min}$ and sample injections of either $30 \mu \mathrm{L}$ or $50 \mu \mathrm{L}$. Samples were eluted using the following gradient: 100\% A in 2 min followed by a linear gradient from 0\% to 95\% B in 18 min 
and held constant for 2 min. At 23 min, solvent B was decreased from $95 \%$ to $0 \%$ and held constant for 3 min.

\subsection{Biological evaluation}

\subsubsection{Anticancer activity}

Anticancer potency was determined as anti-proliferative activity against the human epithelial breast cancer cell line MDA-MB-231 and the human osteosarcoma cell line U2OS. MDA-MB-231 cells were cultivated in RPMI 1640 (Life Technologies) supplemented with 10\% FCS (Invitrogen). U2OS cells were cultivated in DMEM + GlutaMAX (Life technologies), supplemented with 10\% FCS (Invitrogen). All cell lines were maintained at $37^{\circ} \mathrm{C}$ and $5 \% \mathrm{CO}_{2}$. For $\mathrm{IC}_{50}$ determination, cells were seeded on white bottom 96-well plates (Perkin Elmer) at a density of 2 x $10^{4}$ cells/well and rested for $24 \mathrm{~h}$ before exposure to increasing compound concentrations or vehicle (DMSO). After $72 \mathrm{~h}$ incubation, relative amounts of viable cells were determined with CellTiter Glo ${ }^{\circledR}$ Luminiscent Viability Assay (Promega) according to the manufacturer's instructions. Luminescence was measured on an Infinite ${ }^{\circledR} 200$ (Tecan) microplate reader. Each sample was measured in triplicate. Mean IC $_{50}$ values \pm SD were calculated from fitted dose-response curves from at least 3 independent experiments.

\subsubsection{Cell cycle analysis}

Exponentially growing U2OS cells were treated with the indicated concentrations of inhibitor or vehicle for a period of $24 \mathrm{~h}$. Following incubation, cells were collected, washed with PBS (1×), and fixed with ice cold 70\% methanol. Approx. 1 million cells from each sample were stained with 
propidium iodide solution (2.5\% RNase A (Molecular Probes); 1\% propidium iodide (Applichem) in PBS) for 30 min at $37^{\circ} \mathrm{C}$. Cell cycle analysis was then performed on a BD Accuri ${ }^{\mathrm{TM}} \mathrm{C} 6$ flow cytometer. The experiment was performed twice on two different days.

\subsection{Pharmacokinetic assays}

Pharmacokinetic assays were all performed by Cyprotex UK and were analyzed by LC-MS/MS using an internal standard.

\subsubsection{Plasma stability}

Plasma stability was measured in both rat and mouse plasma and given as the percent of parent compound remaining after $2 \mathrm{~h}$ using 5 time points. The assay was run at $37^{\circ} \mathrm{C}$ with a compound concentration of $1 \mu \mathrm{M}$ and at a final DMSO concentration of $2.5 \%$. If necessary, the $\mathrm{pH}$ of the plasma was adjusted to $\mathrm{pH} 7.4$ with either hydrochloric acid or sodium hydroxide. Reactions were

terminated following $0,15,30,60,120$ min by methanol containing internal standard. The sampling plate was centrifuged ( $2500 \mathrm{rpm}, 45 \mathrm{~min}, 4^{\circ} \mathrm{C}$ ) and the supernatants from each point were pooled in cassettes of up to 4 compounds. Samples were analyzed for parent compound by LC-MS/MS using Cyprotex generic analytical conditions. The percentage of parent compound remaining at each time point relative to the 0 min sample was then calculated from LC-MS/MS peak area rations (compound peak area/internal standard peak area).

\subsubsection{Simulated gastric fluid stability}


Incubations were performed at a test or control compound concentration of $1 \mu \mathrm{M}$ in SGF (pH 1.2), at $37^{\circ} \mathrm{C}$. The final DMSO concentration in the incubations was $2.5 \%$. Reactions were terminated following $0,15,30,60$, and 120 min by methanol containing internal standard. The sampling plate was centrifuged (2500 rpm, $45 \mathrm{~min}, 4^{\circ} \mathrm{C}$ ) and the supernatants from each point were pooled in cassettes of up to 4 compounds. Samples were analyzed for parent compound by LC-MS/MS using Cyprotex generic analytical conditions. The percentage of parent compound remaining at each time point relative to the 0 min sample was then calculated from LC-MS/MS peak area rations (compound peak area/internal standard peak area).

\subsubsection{Metabolic stability}

Pooled liver microsomes (male CD1 mice and male Sprague Dawley rats) were purchased from a commercial supplier. Microsomes (final protein concentration $0.5 \mathrm{mg} / \mathrm{mL}$ ), $0.1 \mathrm{M}$ phosphate buffer $\mathrm{pH}$ 7.4, and test compound (final substrate concentration $3 \mu \mathrm{M}$; final DMSO concentration 0.25\%) were pre-incubated at $37^{\circ} \mathrm{C}$ prior to addition of NADPH (final concentration $1 \mathrm{mM}$ ) to initiate the reaction. The final incubation volume was $50 \mu \mathrm{L}$. A control incubation was included for each compound tested, where $0.1 \mathrm{M}$ phosphate buffer $\mathrm{pH} 7.4$ were added instead of NADPH (minus NADPH). Two control compounds were included with each species. All incubations were performed singularly for each test compound, for $0,5,15,30$, and $45 \mathrm{~min}$. The control (minus NADPH) was incubated for 45 min only. The reactions were stopped by transferring $25 \mu \mathrm{L}$ of incubate to $50 \mu \mathrm{L}$ methanol at the appropriate time points. The termination plates were centrifuged at $2500 \mathrm{rpm}$ for $20 \mathrm{~min}$ at $4{ }^{\circ} \mathrm{C}$ to precipitate protein. Following protein precipitation, the sample supernatants were combined in cassettes of up to 4 compounds, internal standard was added and samples were analyzed using Cyprotex generic LC-MS/MS conditions. 


\subsubsection{Plasma protein binding}

Solutions of test compound ( $5 \mu \mathrm{M}, 0.5 \%$ final DMSO concentration) were prepared in buffer (pH 7.4) and $100 \%$ species-specific plasma. The experiment was performed using equilibrium dialysis with the two compartments separated by a semi-permeable membrane. The buffer solution was added to one side of the membrane and the plasma solution to the other side. After equilibrium, samples were taken from both sides of the membrane. Standards were prepared in plasma and buffer and were incubated at $37^{\circ} \mathrm{C}$. Test compounds incubations were performed in duplicate. A control compound was included in each experiment.

The solutions for each batch of compounds were combined into two groups (protein-free and protein-containing), then cassette was analyzed by LC-MS/MS using two sets of calibration standards for protein-free (7 points) and protein-containing solutions (6 points). Cyprotex generic LC-MS/MS conditions were used. Samples were quantified using standard curves prepared in the equivalent matrix. \% fraction unbound $\left(\% \mathrm{f}_{\mathrm{u}}\right)$ was calculated based on duplicate experiments.

\subsection{Thermodynamic solubility}

Saturated PBS solutions of the compounds was prepared by sonication and shaking and the HPLC chromatogram peak areas were used to calculate the respective solubility from the reference graphs. An external standard of benzoic acid in PBS was used and yielded an inter series variance of maximum $1.4 \%$. The deviation in the peak area of benzoic acid in each series from the benzoic acid mean value in all the series was used as a correction factor. 
Two Eppendorf tubes with $1 \mathrm{mg}$ compound in each were prepared (tube A and B). $1 \mathrm{~mL}$ PBS buffer (10 mM phosphate buffer, $2.7 \mathrm{mM} \mathrm{KCl,} 137 \mathrm{mM} \mathrm{NaCl}, \mathrm{pH}$ 7.4) was added to tube A and tube A was subjected to sonication for $10 \mathrm{~min}$ at room temperature (Bransonic 1210E) followed by shaking on a shaking platform for $12 \mathrm{~h}$. Tube A was spun down (14000 rpm, $10 \mathrm{sec}$ ) and the supernatant transferred to a HPLC sample tube (if precipitate was still present in the supernatant, centrifugation was repeated until no precipitate was visible). A reference absorption (at $254 \mathrm{~nm}$ ) graph was made from dilution series of the compounds in MeCN: After $12 \mathrm{~h}$, the compound in test tube B was dissolved in $1 \mathrm{~mL}$ MeCN and diluted further in MeCN to 100, 75, 50, 25, and $10 \mu \mathrm{g} / \mathrm{mL}$. The samples were then analyzed by HPLC starting with the analogue saturated aqueous PBS buffer and then followed by the prepared acetonitrile solutions in the reverse order (low to high concentrations). From the compound peak area(s) in the HPLC chromatograms of the acetonitrile solutions a line fit $(\mathrm{Y}=\mathrm{aX})$ could be obtained and the solubility of the analogue in PBS buffer was calculated from the line's slope and the compound's peak area in PBS buffer.

\subsection{Formulation experiments}

\subsubsection{Manufacturing of test samples}

PEG400 and corn oil: the API candidate was dissolved in PEG400 or corn oil at $70-80{ }^{\circ} \mathrm{C}$ followed by intensive vortex mixing. The final clear solutions were stored in $1.5 \mathrm{ml}$ HPLC vials. PEG8000: the API candidate was dissolved in melted PEG8000 at $90-100{ }^{\circ} \mathrm{C}$ using magnetic stirring. If this method failed, the API was dissolved in PEG400 and the solution was then mixed with melted PEG8000. The hot melted PEG solution was cast as tablets in a plastic mold. WFI injection solution: the API candidate was dissolved in the surfactants at $70-80{ }^{\circ} \mathrm{C}$ and hot water was added 
very slowly. The solution was then cooled down to ambient temperature and stored in $4 \mathrm{~mL}$ HPLC vials.

\subsubsection{Sample preparation for investigating the stability of the formulation experiments}

For WFI formulations, $20 \mu \mathrm{L}$ of sample was diluted to $200 \mu \mathrm{L}$ with Milli-Q water (volume dilution $\mathrm{x}$ 10). For liquid and solid PEG formulations, $200 \mu \mathrm{L}$ liquid or $50 \mathrm{mg}$ solid was added to $1 \mathrm{~mL}$ $\mathrm{CH}_{2} \mathrm{Cl}_{2}$ and $1 \mathrm{~mL}$ Milli-Q water. The aqueous phase was extracted with further $\mathrm{CH}_{2} \mathrm{Cl}_{2}(1 \mathrm{~mL})$ and the combined organic phase washed with Milli-Q water $(1 \mathrm{~mL})$. The organic phase was evaporated in vacuo (including high vacuum oil pump) and the residue dissolved in $0.8 \mathrm{~mL}$ (for liquid samples, volume dilution x 4) or $1 \mathrm{~mL}$ (for solid samples, $20 \mathrm{x}$ dilution) MeCN. The samples were analyzed by HPLC. The aqueous phases from this extraction were also subjected to HPLC analysis and only trace amounts of UV active compounds were found.

\section{Acknowledgements}

This work was supported by the Novo Nordisk Foundation (Pre-seed Grant) and through an instrument grant from the Carlsberg Foundation. NHH received a PhD scholarship from Universiti Sains Malaysia. The authors declare that there is no conflict of interests in regards to the publication. 


\section{References}

[1] A.E. Oxford, H. Raistrick, P. Simonart, Griseofulvin, C(17)H(17)O(6)Cl, a metabolic product of Penicillium griseo-fulvum Dierckx, Biochem. J. 33 (1939) 240-248.

[2] J.C. Gentles, Experimental Ringworm in Guinea Pigs: Oral Treatment with Griseofulvin, Nature. 182 (1958) 476-477.

[3] D.I. Williams, R.H. Marten, I. Sarkany, Oral treatment of ringworm with griseofulvin, Lancet. 2 (1958) 1212-1213.

[4] A.B. Petersen, M.H. Rønnest, T.O. Larsen, M.H. Clausen, The Chemistry of Griseofulvin, Chem. Rev. 114 (2014) 12088-12107.

[5] F. Liéby-Muller, Q. Heudré Le Baliner, S. Grisoni, E. Fournier, N. Guilbaud, F. Marion, Synthesis and activities towards resistant cancer cells of sulfone and sulfoxide griseofulvin derivatives, Bioorganic Med. Chem. Lett. 25 (2015) 2078-2081.

[6] Y.-S. Ho, J.-S. Duh, J.-H. Jeng, Y.-J. Wang, Y.-C. Liang, C.-H. Lin, C.-J. Tseng, C.-F. Yu, R.-J. Chen, J.-K. Lin, Griseofulvin potentiates antitumorigenesis effects of nocodazole through induction of apoptosis and G2/M cell cycle arrest in human colorectal cancer cells, Int. J. Cancer. 91 (2001) 393-401.

[7] T. Oda, Effects of 2'-Demethoxy-2'-propoxygriseofulvin on Microtubule Distribution in Chinese Hamster V79 Cells, Antibiot. 59 (2006) 114-116.

[8] R.A.B. Keates, Griseofulvin at low concentration inhibits the rate of microtubule polymerization in vitro, Biochem. Biophys. Res. Commun. 102 (1981) 746-752.

[9] A.R. Chaudhuri, R.F. Ludueña, Provided for A Hypothesis on the Origin and Evolution of Tubulin, Drug Dev. Res. 53 (2001) 44-49.

[10] B. Rebacz, T.O. Larsen, M.H. Clausen, M.H. Rønnest, H. Löffler, A.D. Ho, A. Krämer, 
Identification of griseofulvin as an inhibitor of centrosomal clustering in a phenotype-based screen, Cancer Res. 67 (2007) 6342-6350.

[11] A. Milunovic-Jevtic, P. Mooney, T. Sulerud, J. Bisht, J.C. Gatlin, Centrosomal clustering contributes to chromosomal instability and cancer, Curr. Opin. Biotechnol. 40 (2016) 113118.

[12] D. Bhakta-Guha, M.E.M. Saeed, H.J. Greten, T. Efferth, Dis-organizing Centrosomal Clusters: Specific Cancer Therapy for a Generic Spread?, Curr. Med. Chem. 22 (2015) 685694.

[13] N. Korzeniewski, M. Hohenfellner, S. Duensing, The centrosome as potential target for cancer therapy and prevention, Expert Opin. Ther. Targets. 157 (2012) 1-10.

[14] M.H. Rønnest, B. Rebacz, L. Markworth, A.H. Terp, T.O. Larsen, A. Krämer, M.H. Clausen, Synthesis and structure-activity relationship of griseofulvin analogues as inhibitors of centrosomal clustering in cancer cells, J. Med. Chem. 52 (2009) 3342-3347.

[15] M.H. Rønnest, M.S. Raab, S. Anderhub, S. Boesen, A. Krämer, T.O. Larsen, M.H. Clausen, Disparate SAR data of griseofulvin analogues for the dermatophytes Trichophyton mentagrophytes, T. rubrum, and MDA-MB-231 cancer cells, J. Med. Chem. 55 (2012) 652660.

[16] A.B. Petersen, G. Konotop, N.H.M. Hanafiah, P. Hammershøj, M.S. Raab, A. Krämer, M.H. Clausen, Strategies for improving the solubility and metabolic stability of griseofulvin analogues, Eur. J. Med. Chem. 116 (2016) 210-215.

[17] M.S. Raab, I. Breitkreutz, S. Anderhub, M.H. Rønnest, B. Leber, T.O. Larsen, L. Weiz, G. Konotop, P.J. Hayden, K. Podar, J. Fruehauf, F. Nissen, W. Mier, U. Haberkorn, A.D. Ho, H. Goldschmidt, K.C. Anderson, M.H. Clausen, A. Krämer, GF-15, a novel inhibitor of centrosomal clustering, suppresses tumor cell growth in vitro and in vivo, Cancer Res. 72 
(2012) 5374-5385.

[18] A.I. Arida, M.M. Al-Tabakha, H.A.J. Hamoury, Improving the high variable bioavailability of griseofulvin by SEDDS., Chem. Pharm. Bull. (Tokyo). 55 (2007) 1713-1719.

[19] L. Stephenson, T. Walker, W.K. Warburton, G.B. Webb, Griseofulvin Analogues. Part IV. The Preparation and Properties of Some Chlorides, J. Chem. Soc. 4 (1962) 1282-1292.

[20] S.H. Yalkowsky, Y. He, P. Jain, Handbook of Aqueous Data, 2nd ed., CRC Press, 2010.

[21] V.N. Viswanadhan, A.K. Ghose, G.R. Revankar, R.K. Robins, Atomic Physicochemical Parameters for Three Dimensional Structure Directed Quantitative Structure-Activity Relationships . 4 . Additional Parameters for Hydrophobic and Dispersive Interactions and Their Application for an Automated Superposition of Certai, J. Chem. Inf. Comput. Parameters Three Dimens. Struct. Dir. Quant. Struct. Relationships . 4 . Addit. Parameters Hydrophobic Dispersive Interact. Their Appl. an. 29 (1989) 163-172.

[22] D.S. Pedersen, C. Rosenbohm, Dry column vacuum chromatography, Synthesis (Stuttg). 16 (2001) 2431-2434. 


\section{List of captions}

\subsection{Figures}

Figure 1. Chemical structure of griseofulvin (1) with IUPAC recommended numbering and ring designation and the 2'-benzyloxy griseofulvin analogue 2 .

Figure 2. Previously reported 2'-oxy modified griseofulvin analogues with antiproliferative activity comparable to compound 2.

Figure 3. The four 2'-amino analogues 10-13 and two 2'-phenethyl modified compounds 14 and 15.

Figure 5: Cell cycle analysis of exponentially growing U2OS cells treated with griseofulvin (1), analogue 10, or vehicle (DMSO) for 24 hours. A) Cell cycle distribution showing the percentages of cells in G0/G1, S, and G2/M phases. Bars indicate averages \pm SD from two independent experiments. B) Examples of representative cell cycle histograms based on gated propidium iodide staining. Bars indicate cell populations in the G0/G1 (M1) and G2/M (M2) phases, respectively.

\subsection{Schemes}

Scheme 1. Overview of the synthetic strategy used for preparation of the 2'-modified griseofulvin analogues with the general structure $\mathbf{5}$. 


\subsection{Tables}

Table 1. Anticancer activity of griseofulvin and analogues against two human cancer cell lines.

Table 2. Pharmacokinetic data on compounds 1-13.

Table 3. Thermodynamic solubility and clogP of $\mathbf{1}$ and the most promising analogues, compounds 2, 9, and 10.

Table 4. Stability study of analogues $\mathbf{2 ,} \mathbf{9}$, and $\mathbf{1 0}$ in three different types of dosage forms. Positive $(+)$ stabilities were assigned when the compounds did not show signs of degradation in their respective chromatograms after 30 days at the described conditions. The concentration of API was 5 mg/mL for PEG400 and PEG8000 and $1 \mathrm{mg} / \mathrm{mL}$ liquid WFI, unless otherwise stated. 